\title{
PENGARUH LAPORAN KEUANGAN PERUSAHAAN TERHADAP KEPUTUSAN PEMBERIAN KREDIT MODAL KERJA
}

\author{
ALAILA SAGERI, MUH. YUSUF Q, I KETUT PATRA
}

\begin{abstract}
ABSTRAK
Bagi bank umum, kredit merupakan sumber utama penghasilan, sekaligus sumber operasi bisnis terbesar, sebagian besar dana operasional bank umum diputarkan dalam bentuk kredit. Dalam menyalurkan dananya, pihak perbankan atau kreditor memiliki syarat tertentu yang harus dipenuhi. Sebelum pinjaman atau kredit dikucurkan, bank terlebih dahulu menganalisis kelayakan usahanya salah satunya adalah dengan menganalisis laporan keuangan perusahaan untuk beberapa periode tertentu.

Penelitian tentang Pengaruh Laporan Keuangan Perusahaan Terhadap Keputusan Pemberian Kredit Modal Kerja bertujuan untuk mengetahui seberapa besar pengaruh laporan keuangan terhadap keputusan pemberian kredit modal kerja pada PT. Bank Sulsel Cabang Masamba jika dihubungkan dengan fenomena yang terjadi disekeliling, tidak sedikit juga orang yang berpendapat bahwa laporan keuangan tidak berperan secara mutlak, melainkan masih banyak faktor-faktor lain yang mempengaruhinya seperti faktor jaminan, faktor 5 C (Character, Capacity, Capital, Collateral dan Condition), faktor kekeluargaan dan sebagainya sehingga permohonan kredit tersebut ditolak atau diterima.

Adapun metode analisis yang digunakan adalah regresi linier sederhana dengan menggunakan software SPSS Versi 17.0. Daftar pertanyaan/kuesioner (indicator) yang ditujukan sebagai alat ukur penenelitian. Setiap jawaban yang diberi skor numeric (angka 1-5) untuk menentukan pendapat karyawan tentang pengaruh laporan keuangan perusahaan terhadap pemberian kredit modal kerja

Dari hasil penelitian menunjukkan bahwa PT. Bank Sulsel cabang Masamba dalam memutuskan pemberian kredit modal kerja lebih melihat aspek laporan keuangan calon debitur, dimana laporan keuangan berpengaruh positif terhadap keputusan pemberian kredit modal kerja pada sebuah perusahaan, atau dengan kata lain variabel laporan keuangan berpengaruh positif dan signifikan dengan variabel keputusan pemberian kredit pada PT. Bank Sulsel cabang Masamba sebesar 1,034 dengan tingkat signifikansi sebesar 0,010
\end{abstract}

Kata kunci: Laporan Keuangan perusahaan, Keputusan pemberian kredit, Modal kerja 


\section{Pendahuluan}

\section{Latar Belakang}

Persaingan bisnis dewasa ini semakin meningkat dari tahun ke tahun, hal ini dapat dilihat dari banyaknya usaha bisnis yang bergerak pada sektor jasa, khususnya jasa keuangan. Sebagai lembaga penghimpun dan penyaluran dana dari masyarakat.

Apabila kebutuhan dana besar, sementara dana yang dibutuhkan tidak tersedia maka pemenuhan dana dari lembaga-lembaga seperti bank melalui dana pinjaman sangat dibutuhkan. Dalam prakteknya dana yang dibutuhkan perusahaan ada dua macam, yaitu untuk keperluan modal kerja dan investasi. Usaha keuangan dilaksanakan oleh perusahaan yang bergerak di bidang keuangan atau yang sering kita sebut dengan lembaga keuangan.

Menurut Kasmir (2003:2) menyatakan bahwa : "Lembaga Keuangan adalah setiap perusahaan yang bergerak di bidang keuangan, menghimpun dana, menyalurkan dana atau kedua-duanya." Kegiatan menghimpun dana dapat berupa mengumpulkan dana dari masyarakat dalam bentuk simpanan, giro, tabungan, dan deposito. Selain itu bank juga menyalurkan dana kepada masyarakat dalam bentuk kredit untuk meningkatkan tarif hidup rakyat banyak. Bagi bank umum, kredit merupakan sumber utama penghasilan, sekaligus sumber resiko operasi terbesar.

Bank Pembangunan Daerah (BPD) Sulawesi Selatan yang dikenal dengan sebutan Bank Sulsel merupakan salah satu Badan Usaha Milik Daerah (BUMD), milik Pemerintah Propinsi Sulawesi Selatan. Badan usaha tersebut menyediakan layanan jasa perbankan sebagaimana bank-bank umum pemerintah dan umum swasta nasional lainnya.

Keputusan pemberian kredit, pada umumnya berdasarkan pada analisis kredit yang dilakukan pada saat pengajuan permohonan kredit oleh nasabah. Ada dua jenis analisis yang dapat dilakukan untuk keputusan pemberian kredit, yaitu Analisis terhadap data kuantitatif dan Analisis data Kualitatif. Pada analisis kuantitatif, laporan keuangan dapat membantu pihak bank untuk memperoleh kondisi keuangan perusahaan yang nantinya akan dibiayai oleh bank. Dengan adanya laporan keuangan maka pihak bank sangat mudah dalam mempertimbangkan pada keputusan pemberian kredit.

Sedangkan pada analisis kualitatif, penyaluran kredit kepada nasabah yang membutuhkan kredit harus melalui suatu prosedur yang harus dilakukan secara profesional yang bersifat kehati-hatian. Dimana prosedur tersebut mungkin berbeda antara suatu bank dengan bank lainnya, namun secara umum dapat dijelaskan bahwa tahapan-tahapan penyaluran kredit tersebut dari wawancara dengan calon debitur, analisis laporan keuangan, penilaian jaminan, pemeriksaan dokumen-dokumen hukum sampai pada tahap memutuskan kredit yang biasanya diputuskan oleh pejabat-pejabat bank.

Dari uraian tersebut diatas peneliti bermaksud untuk melakukan penelitian mengenai "Pengaruh Laporan Keuangan Perusahaan Terhadap Keputusan Pemberian 
Kredit Modal Kerja pada PT. Bank Sulsel Cabang Masamba. Masalah dalam penelitian adalah Apakah Laporan Keuangan Perusahaan Berpengaruh Dalam Keputusan Pemberian Kredit Modal Kerja?. Tujuan dari penelitia ini adalah untuk mengetahui besarnya pengaruh laporan keuangan perusahaan dalam keputusan pemberian kredit modal kerja.

\section{Metode Penelitian}

Tempat dan Waktu Penelitian

Untuk memperoleh data yang dibutuhkan dalam penelitian ini, penulis mengadakan penelitian pada PT Bank Sulsel Cabang Masamba, yang beralamatkan dijalan Suhada No. 1 Masamba. Adapun waktu penelitian kurang lebih dua bulan.

Jenis dan Sumber Data

1. Data Primer

2. Data Sekunder

Populasi dan Sampel

Populasi yang ada dalam penelitian ini adalah seluruh pegawai yang berhubungan dengan proses pemberian kredit yang berjumlah 6 karyawan (tidak termasuk pimpinan pada PT. Bank Sulsel Cabang Masamba). Sedangkan sampel juga berjumlah 6 karyawan, berarti populasi sama dengan sampel karena jumlahnya yang sedikit.

Metode Pengumpulan Data

Metode pengumpulan data yang digunakan adalah: (a) Observasi; Yaitu teknik pengumpulan data dengan cara mengadakan pengamatan secara langsung dilapangan untuk memperoleh data yang akurat, (b) Wawancara (interview); Yaitu teknik pengumpulan data dengan cara mengajukan pertanyaan secara langsung pada pihak-pihak yang berhubungan dengan penelitian ini, (c) Daftar pertanyaan (Kuesioner); Yaitu teknik pengumpulan data dengan cara menyusun daftar pertanyaan tertulis, yang kemudian diajukan kepada responden yang terkait dalam penelitian ini.

Metode Analisis Data

Metode analisis yang digunakan adalah metode analisis regresi sederhana, dengan formulasi yang dapat digunakan untuk mencari a dan $\mathrm{b}$ adalah :

$$
\begin{aligned}
& a=\frac{\sum \mathrm{y}}{\mathrm{n}} \\
& b=\frac{\sum \mathrm{x}}{\mathrm{N}}
\end{aligned}
$$


Keterangan :

$\bar{X}_{i}=$ Rata-rata skor variabel $\mathrm{X}$

$\bar{Y}_{\mathrm{i}}=$ Rata-rata skor variabel $\mathrm{Y}$

\section{Hasil Penelitian Dan Pembahasan}

\section{Prosedur Pemberian Kredit}

Prosedur Pemberian Kredit PT. Bank Sulsel Cabang Masamba

Pada surat keputusan Direksi Bank Indonesia No. 23/69/KEP/DIR tanggal 28 Februari 1991 tentang jaminan disebutkan antara lain :

Pasal 1a, jaminan pemberian kredit adalah keyakinan bank atas kesanggupan debitur untuk melunasi kredit sesuai dengan yang diperjanjikan.

Pasal 2a, bank tidak diperkenankan memberikan kredit kepada siapapun tanpa jaminan.

Masalah jaminan harus dipertegas untuk mengurangi resiko kredit yang besar, maka harus ada jaminan dalam setiap kredit yang diberikan. Antara lain bank dapat membuat kebijakan :

a. Besarnya kredit harus sebanding dengan jaminan, bagaimanapun bentuk hubungan yang ada antara bank dengan nasabah.

b. Jaminan yang akan diberikan harus dinilai dengan seksama, misalnya apa wujud dari jaminan tersebut, bagaimana nilainya dimasa sekarang ataupun dimasa yang akan datang.

Proses Pengawasan Kredit

Prosedur pengawasan kredit meliputi dua cara yaitu :

1. Pembinaan yang bersifat administrasi yang lebih menitikberatkan kepada kegiatan Account Officer di dalam kantor.

2. Pembinaan langsung ke lapangan untuk membantu langsung kesulitan serta kelancaran usaha debitur, Account Officer dituntut pula untuk mengetahui perkembangan usaha yang dilakukan dibitur.

Tujuan pengawasan kredit ini dilakukan agar setiap kredit yang diberikan sehat, artinya :

1. Penggunan kredit sesuai tujuannya

2. Memenuhi presyaratan kredit, baik administrasi maupun yuridis

3. Pengembalian kredit berjalan lancar sesuai perjanjian

4. Mencegah timbulnya kerugian bagi bank maupun debitur, sebagai akibat penyimpanan atau penyelenggaraan yang dilakukan oleh bank, oleh debitur maupun oleh pihak ketiga, 


\section{Analisis Deskriptif Data Penelitian}

Penelitian ini menggunakan analisis kuantitatif dengan metode pengumpulan data berupa angket (kuesioner) yang ditunjukkan kepada Bank Sulsel untuk keperluan pengumpulan data sebagai bahan analisis.

\section{Gambaran Deskriptif Laporan Keuangan}

Variabel laporan keuangan terdiri dari 7 item pernyataan. Item pernyataan tersebut meliputi: Laporan keuangan merupakan onjek utama untuk melakukan analisis atas permohonan kredit modal kerja (item 1), pihak bank melakukan analisis atas neraca yang dimiliki oleh pemohon kredit modal kerja (item 2), pihak bank melakukan analisis atas laporan L/R yang dimiliki oleh pemohon kredit modal kerja (item 3), analisis terhadap Neraca dan Laporan L/R sudah menjadi aspek penilaian dalam penentuan keputusan terhadap usulan pemohon kredit modal kerja (item 4), salah satu cara penilaian terhadap laporan keuangan dari pemohon kredit modal kerja dengan menggunakan arus kas (item 5), pihak bank harus menganalisis laporan keuangan tersebut secara jelas dan sebenarnya (item 6), laporan keuangan yang dianalisis oleh pihak bank adalah laporan keuangan yang menggambarkan pada periode tertentu kondisis keuangan (item 7).

Item variabel tersebut dapat di deskripsikan sebagai berikut : item 1, item 6 , dan item 7 masing-masing memiliki skor 25. Skor tersebut mengindikasikan bahwa ketiga aktivitas tersebut dilaksanakan pada PT. Bank Sulsel Cabang Masamba. Item 5 dengan skor 24, skor tersebut mengindikasikan bahwa arus kas digunakan dalam penilaian laporan keuangan pemohon kredit pada PT. Bank Sulsel Cabang Masamba.

Item 4 dengan skor 23, skor tersebut mengindikasikan bahwa neraca dan laporan L/R digunakan dalam penilaian laporan keuangan pada PT. Bank Sulsel Cabang Masamba. Item 2 dan item 3, masing-masing memiliki skor 22. Skor tersebut mengindikasikan bahwa kedua aktivitas tersebut dilaksanakan pada PT. Bank Sulsel Cabang Masamba.

\section{Gambaran Deskriptif Keputusan Pemberian Kredit}

Variabel keputusan pemberian kredit terdiri dari 7 item pernyataan. Item pernyataan tersebut meliputi : untuk mengetahui kejujuran dan itikad baik calon debitur dalam melunasi atau mengembalikan pinjaman, pihak Bank melakukan penilaian terhadap kepribadian atau watak pemohon kredit modal kerja (item 1), dilakukannya penilaian watak (character) terhadap latar belakang pekerjaan maupun kepribadian calon debitur dimaksudkan agar tidak akan menyulitkan Bank dikemudian hari (item 2), pihak Bank melakukan penilaian kemampuan (capacity) terhadap calon debitur dalam bidang usaha dan kemampuan manajerialnya (item 3), untuk melihat penggunaan modal (capital) apakah efektif, dilihat pada laporan keuangan (Neraca dan Laba/Rugi) (item 4), calon debitur diwajibkan memberikan jaminan yang berkualitas tinggi yang mudah dicairkan sesuai dengan jumlah kredit yang akan diberikan (item 5), dalam penilaian jaminan harus diteliti keabsahannya 
sehingga tidak menyulitkan Bank dikemudian hari, dalam penilaian terhadap prospek usaha calon debitur, pihak bank harus menganalisis kondisi ekonomi dimasa sekarang dan akan datang sesuai sektor masing-masing.

Item variabel tersebut dapat dideskripsikan sebagai berikut : item 4 dengan skor 31 mengindikasikan bahwa penilaian terhadap modal (capital) telah dilaksanakan pada PT. Bank Sulsel Cabang Masamba. Item 1 dengan skor 27 mengindikasikan bahwa aktivitas dalam penilaian watak (character) dilaksanakan pada PT. Bank Sulsel Cabang Masamba. Item 7 dengan skor 26 mengindikasikan bahw aktivitas tersebut dilaksanakan pada PT. Bank Sulsel Cabang Masamba. Item 2 dengan skor 25 mengidikasikan bahwa penilaian tentang watak terhadap latar belakang pekerjaan maupun kepribadian calon debitur telah dilaksanakan pada PT. Bank Sulse Cabang Masamba. Item 3 dengan skor 24 mengindikasikan bahwa aktivitas dalam penilaian kemampuan terhadap calon debitur dilaksanakan pada PT. Bank Sulsel Cabang Masamba. Item 6 dengan skor 22 mengindikasikan bahwa aktivitas penilaian jaminan dalam penilaian keabsahannya telah dilaksanakan pada PT. Bank Sulsel Cabang Masamba. Item 5 dengan skor 19 mengindikasikan bahwa aktivitas penilian jaminan telah dilaksanakan PT. Bank Sulsel Cabang Masamba.

\section{Analisis Infrensial Hasil Penelitian}

Hasil Persamaan Regresi

\begin{tabular}{|c|c|c|c|c|c|}
\hline \multirow[b]{2}{*}{ Model } & \multicolumn{2}{|l|}{$\begin{array}{l}\text { Unstandardize } \\
\text { d Coefficients }\end{array}$} & \multirow{2}{*}{$\begin{array}{l}\text { Standardiz } \\
\text { ed } \\
\text { Coefficien } \\
\text { ts } \\
\text { Beta }\end{array}$} & \multirow[b]{2}{*}{$\mathrm{t}$} & \multirow[b]{2}{*}{ Sig } \\
\hline & B & $\begin{array}{l}\text { Std. } \\
\text { Error }\end{array}$ & & & \\
\hline $\begin{array}{l}\begin{array}{l}1 \\
\text { (Constant) } \\
\text { X_total }\end{array} \\
\text { X_tol }\end{array}$ & $\begin{array}{r}.057 \\
1.034\end{array}$ & $\begin{array}{r}6.258 \\
.225\end{array}$ & .917 & $\begin{array}{r}.009 \\
4.586\end{array}$ & $\begin{array}{l}.993 \\
.010\end{array}$ \\
\hline
\end{tabular}

a. Dependent Variabel: y_total

Dari tabel diatas, diketahui bahwa persamaan regresi yang telah dirumuskan dengan bantuan program SPSS Versi 17.0, didapat persamaan sebagai berikut :

$$
\mathbf{Y}=\mathbf{0 , 0 5 7}+\mathbf{1 . 0 3 4} \mathbf{X}
$$

Berdasarkan persamaan diatas, maka niali konstanta $\mathrm{a}=0,057$, artinya jika nilai variabel X (laporan keuangan) adalah 0 (nol) atau dengan lain variabel X tidak ada, maka keputusan pemberian kredit pada PT. Bank Sulsel Masamba sebesar 0,057 .

Nilai $b=1,034$ dapat diartikan bahwa keputusan pemberian kredit dipengaruhi oleh laporan keuangan sebesar 1,034 atau dengan kata lain setiap kenaikan kinerja laporan keuangan 1 persen berpengaruh terhadap kenaikan keputusan kredit sebesar 1,034 persen. Jadi dari persamaan regresi diatas menunjukkan hubungan ada pengaruh positif antara variabel dependen (keputusan pemberian kredit) dengan variabel independen (laporan keuangan). 
Analisis Koefisien Determinasi $\left(\mathbf{R}^{2}\right)$

Model Summary ${ }^{\mathrm{b}}$

\begin{tabular}{|c|c|c|c|c|}
\hline Model & $\mathrm{R}$ & R Square & $\begin{array}{l}\text { Adjusted R } \\
\text { Square }\end{array}$ & $\begin{array}{l}\text { Std. Error of } \\
\text { The Estimate }\end{array}$ \\
\hline 1 & $.917^{\mathrm{a}}$ & .840 & .800 & 1.22126 \\
\hline
\end{tabular}

a. Predictors: (Constant), $\mathrm{x}$ _total

b. Dependent variable: $y_{-}$total

Dari tabel diatas diperoleh nilai $\mathrm{R}$ (korelasi) sebesar 0.917 atau 91,7\%. Menunjukkan antara variabel Y (keputusan pemberian kredit) dengan variabel bebas $\mathrm{X}$ (laporan keuangan) ada hubungan yang sangat kuat. Sedangkan nilai determinasi $\mathrm{R}^{2}$ adalah sebesar 0.840 menunjukkan pengaruh laporan keuangan terhadap keputusan kredit sebesar $84.0 \%$, sedangkan sisanya sebesar $16,0 \%$ dijelaskan oleh variabel lain yang tidak diperhitungkan dalam model.

\section{Pengujian Hipotesis}

Pada penelitian ini, uji $t$ digunakan untuk menguji apakah hipotesis yang diajukan dalam penelitian ini diterima atau ditolak dengan mengetahui apakah variabel laporan keuangan secara individual mempengaruhi variabel keputusan pemberian kredit. Koefisien t hitung variabel laporan keuangan (X) sebesar 4,586 signifikan 5 persen, maka hipotesis nihil ditolak dan hipotesis alternatif diterima. Berarti variabel laporan keuangan secara individual mempengaruhi variabel keputusan pemberian kredit. Dengan demikian hipotesis yang menyatakan bahwa laporan keuangan berpengaruh positif terhadap keputusan pemberian kredit diterima kebenarannya.

Dengan adanya laporan keuangan maka pihak bank dapat memperoleh gambaran mengenai kondisi keuangan perusahaan yang akan dibiayai dan menjadi sumber informasi penting sebagai salah satu bahan pertimbangan dalam mengambil keputusan pemberian kredit.

Dari hasil penelitian yang dilakukan pada PT. Bank Sulsel Cabang Masamba, maka dapat diketahui bahwa Laporan Keuangan dari calon Debitur memberikan kontribusi $0,840 \%$ terhadap keputusan pemberian kredit.

\section{Penutup}

Kesimpulan dari penelitian ini bahwa laporan keuangan dari calon debitur berpengaruh terhadap keputusan pemberian kredit. Adapun saran yang dapat diberikan oleh penulis agar menjadi masukan bagi PT. Bank Sulsel Cabang Masamba, yaitu : (a) Dalam pemberian kredit pada PT. Bank Sulsel cabang Masamba, tidak boleh berpihak kepada siapapun, meskipun itu keluarga/orang-orang terdekat dengan begitu prosedur dalam pemberian kredit akan berjalan sesuai dengan tujuannya dan memperkecil kemungkinan terjadinya kredit macet, (b) Sebaiknya PT. 
Bank Sulsel Cabang Masamba, meningkatkan kinerja dalam hal pemberian kredit modal kerja. Bukan hanya kredit untuk perusahaan tetapi juga memberikan kredit perorangan, agar Bank Sulsel Cabang Masamba bisa meningkatkan pendapatan perusahaan dan mengurangi resiko dana funding yang menganggur di kas.

\section{Daftar Pustaka}

Anonim, 2009, Standar Akuntansi Keuangan, Edisi Revisi, PT. Rineka Cipta, Jakarta.

Dewi, Lely Savitri, 1996, Strategi dan Operasinal Bank, Cetakan Pertama, PT. Eresco, Bandung.

Djohan, Warman, 2000, Kredit Bank : Alternatif pembiayaan dan Pengajuan, PT. Mutiara Sumber Widya, Jakarta.

Fauziah, 2001, Persepsi Nasabah Terhadap Peranan Laporan Keuangan Nasabah Dalam Pengambilan Keputusan Kredit. Skripsi (Fakultas Ekonomi Universitas Muhammadiyah Surakarta)

Firdaus, Yoga, dan Sadeli, Lili M, H 2008, Dasar-Dasar Akuntansi, Cetakan Empat, Penerbit PT. Bumi Aksara, Jakarta.

Ghozali, Imam. 2002. Aplikasi Analisis Mulivariat dengan Program SPSS. Semarang: Badan Penerbit Unibersitas Diponogoro

Hadiwijaya, H, dan Wirasasmita, R.A. Rivai, 1991. Analisis Kredit, Cetakan Pertama, Penerbit Pionir Jaya, Bandung.

Herianto, Adrie, Yulianto, 2006, Peranan Analisis Laporan Keuangan Dalam Efektivitas Penilaian Permohonan Kredit. Skripsi (Fakultas Ekonomi Widyatama Bandung).

Jusuf, Jopie, 2005, Analisis Kredit untuk Account Officer, Cetakan Keenam, PT Gramedia Pustaka Utama Jakarta.

Kasmir, 2003, Bank Dan Lembaga Keuangan Lainny, Edisi Keeanam, Cetakan Ketujuh, PT Raja Grafindo Persada Jakarta.

Santoso, Singgih, 2001. Buku Latihan SPSS Statistik Parametrik, Edisi Pertama. Jakarta: PT. Elex Media Komputindo. 
Alaila Sageri et al - PENGARUH LAPORAN KEUANGAN PERUSAHAAN TERHADAP KEPUTUSAN....

Suprant, J, 2001, Statistik, Edisi Keenam, Cetakan Pertama, Erlangga, Jakarta.

Suhardjono. 2003. Manajemen Perkreditan Usaha Kecil dan Menengah, UPP AMP YKPN, Yogyakarta.

Suryabrata, Sumardi, 2007, Metodologi Penelitian, CV. Rajawali, Jakarta.

Undang-Undang Republik Indonesia Nomor 10 Tahun 1998, Perbankan, Sinar Grafika, Jakarta. 